\title{
Prevalence of Psittacine Beak and Feather Disease Virus and Avian Polyomavirus in Captivity Psittacines from Costa Rica"
}

\author{
Gaby Dolz ${ }^{1,2 \#}$, Jessica Sheleby-Elías², Juan J. Romero-Zuñiga ${ }^{1,2}$, Bernardo Vargas-Leitón ${ }^{1,2}$, \\ Gustavo Gutiérrez-Espeleta ${ }^{3}$, Kenneth Madriz-Ordeñana ${ }^{4}$ \\ ${ }^{1}$ Laboratorio de Entomología y Medicina Poblacional, Programa MEDPOB, Escuela de Medicina \\ Veterinaria, Universidad Nacional, Heredia, Costa Rica \\ ${ }^{2}$ Maestría en Enfermedades Tropicales, Posgrado Regional en Ciencias Veterinarias \\ Tropicales, Escuela de Medicina Veterinaria, Universidad Nacional, Heredia, Costa Rica \\ ${ }^{3}$ Escuela de Biología, Universidad de Costa Rica, San José, Costa Rica \\ ${ }^{4}$ Biotécnica Análisis Moleculares, San José, Costa Rica \\ Email: "gaby.dolz.wiedner@una.cr, juan.romero.zuniga@una.cr, bernardo.vargas.leiton@una.cr, jessicasheleby@gmail.com, \\ gustavo.gutierrez@ucr.ac.cr, kmor@life.ku.dk
}

Received June 22, 2013; revised July 22, 2013; accepted July 30, 2013

Copyright (C) 2013 Gaby Dolz et al. This is an open access article distributed under the Creative Commons Attribution License, which permits unrestricted use, distribution, and reproduction in any medium, provided the original work is properly cited.

\begin{abstract}
Psittacine beak and feather disease virus (PBFDV) and avian polyomavirus (APV) are the most common viral diseases in psittacine birds, both affecting feathers and physical appearance of birds. Between 2005 and 2009, a total of 269 samples were collected from birds presented at veterinary clinics, shelters and rescue centers of wildlife in Costa Rica. They belonged to 19 species of psittacine birds. The most representative species in the sample were Ara macao (157), Ara ambigua (37), Amazona autumnalis (24), Amazon ochrocephala (21) and Ara ararauna (8). A prevalence of 19.7\% (53/269) for PBFDV and 4.8\% (13/269) for APV was determined using Polymerase Chain Reaction (PCR). In 3.3\% (9/269) of the birds mixed infections were detected. Statistical analysis determined that psittacines living in shelters and rescue centers had a greater risk to be positive to PBFDV and APV than birds that were presented at veterinary clinics, while only for PBFDV it was determined, that it is more likely to detect it in feathers than in blood. Finally, birds infected with PBFDV had 6.24 times more probability to become infected with APV, than non-infected birds. This is the first report of prevalence of PBFDV and APV in captive psittacines from Costa Rica.
\end{abstract}

Keywords: Psittacine Beak and Feather Disease Virus; Avian Polyomavirus; Psittacine Birds; Costa Rica

\section{Introduction}

Psittacine beak and feather disease virus (PBFDV) and avian polyomaviurs (APV) cause serious and often fatal disease in parrots and other bird species [1]. PBFDV belongs to the family Circoviridae affecting about 60 species of psittacines [1,2]. The disease is progressive and irreversible, and characterized by progressive dystrophy and loss of feathers, sometimes associated with deformities of the beak [3] and immunosupression [4,5]. Transmission occurs horizontally and vertically [6]. PBFDV replicates in a variety of tissues, including thymus, bursa, crop, esophagus, intestine, skin and feathers, also it has been identified in circulating leukocytes [5].

${ }^{*}$ Conflict of interest: No conflict of interest is declared.

${ }^{\#}$ Corresponding author.
The virus has been detected at high concentrations especially in the dust of feathers [7]. The majority of infected birds survive less than one year after clinical symptoms appear, although subclinical carrier birds, surviving 10 years without feather problems have been reported $[2,8,9]$. The outcome of infection depends on the age at which the bird was exposed to the virus, maternal antibody levels, route of infection and the amount of virus that the bird was exposed to. All these factors determine if the animal will raise a good immune response [6]. Death usually occurs due to secondary infections by bacteria, fungi or other viruses $[2,8,9]$. Avian polyomavirus (APV) cause budgerigar fledgling disease and is characterized by abnormalities and loss of feathers of budgerigar offspring and chicks [10-12]. The host 
range of APV is very broad, affecting not only Psittaciformes but also other orders of birds [13-16]. The infection causes sudden death, abdominal distension, and feather abnormalities, lack of feathers on the back, abdomen, head and neck; and also subcutaneous hemorrhages have been reported in parakeets $[10,17]$. Young birds that survive the infection usually recover and become asymptomatic carriers. Infection in adult birds is generally subclinical and persistent, only occasionally developing symptoms [6].

Diagnosis of PBFDV and APV based on external lesions is difficult, since both diseases resemble each other. Recently, detection of viral DNA in blood and feathers has been used, since it is a sensitive, specific and rapid assay, which may detect also subclinical carriers. Primers designed to amplify a fragment of the capsid protein region encoded by the conserved orfC1 gene of PBFDV genome has been reported to detect all PBFDV variants in psittacine birds. Remarkable differences have been found between mammalian polyomaviruses and APV especially in the non-coding regulatory region and in the regions encoding the large tumour $(\mathrm{T})$ antigen, therefore the amplification of $\mathrm{t} / \mathrm{T}$ antigen region of APV genome is used, and shows conservation in all APV-positive samples as expected [18].

Reported viral DNA positive rates in different countries vary for PBFDV from $3.5 \%$ in the USA [19] and $8.05 \%$ in Italy [20] to $40.4 \%$ in Germany [21] and $41.2 \%$ in Taiwan [22], and for APV, from $0.8 \%$ in Taiwan [22] to $15.2 \%$ in Italy [20].

PBFDV and APV are recognized as threats for endangered psittacine birds. In Costa Rica, a total of $9.37 \%$ of macaws in captivity showed antibodies against APV using a blocking ELISA and serumneutralization test [23], however presence of PBFDV was not reported to date. The aim of the present study was to determine the prevalence of PBFDV and APV in captivity psittacines in Costa Rica.

\section{Materials and Methods}

\subsection{Size, Type of Sample and Data Collected from the Analyzed Birds}

Approximately 140,200 parrots and parakeets were estimated to live illegally in captivity in households in Costa Rica in 2002 [24]. To determine prevalence of PBFDV and APV, the formula described by Wayne [25] was used, using an expected prevalence of $20 \%$ [20,22,23], a $95 \%$ confidence level, and a 5\% sampling error. A sample size of 246 birds to analyze was determined, however, a total of 269 samples from psittacine birds were collected between 2005 and 2009 and analyzed in the present study. From these, 142 samples came from a blood DNA bank of red and green macaws (Ara macao and Ara ambigua), which were collected between 2005 and 2007 from veterinary clinics, shelters and rescue centers in different provinces of the country. These samples were previously used in genetic and sexing studies and only information of province and species was obtained. The remaining 120 samples were collected during 2009, from veterinary clinics, shelters and rescue centers from different provinces of the country. Of these birds, a blood sample with anticoagulant (EDTA) and 3 to 4 chest feathers with quill were collected and preserved a maximum of five days at $4^{\circ} \mathrm{C}$; once in the laboratory, the swabs and feathers were kept at $-20^{\circ} \mathrm{C}$ until DNA extraction and molecular analysis was performed. In addition, a clinical survey was carried out, to collect following data from the birds: species, province of origin, age and clinical symptoms related with PBFDV and APV (feather abnormality and beak deformity). The distribution of the psittacines analyzed in the present study by origin, province and species is presented in Tables $\mathbf{1}$ and $\mathbf{2}$, respectively.

\subsection{Polymerase Chain Reaction (PCR)}

DNA extraction was performed using the DNeasy ${ }^{\circledR}$ Blood \& Tissue Kit according to manufacture's instructtions (QIAGEN). For detection of PBFDV, a PCR protocol described by Raue et al. [26] was used, which amplifies a region of $202 \mathrm{bp}$ of the highly conservated orfC1 gene. The primers used were: circo-s: 5'-CGG TGC CAG AAA ATG GTA TGT TAG-3' and, circo-as: 5 '-GAA GCT GAA GCC AAT GCC GTA-3’. For detection of APV, the protocol described by Johne and Müller [14] was used, which amplifies a segment of $310 \mathrm{bp}$ of the antigen $t / T$ of the genome, using the following primers: 5 '-CAA GCA TAT GTC CCT TTA TCC C-3' and: 5 -CTG TTT AAG GCC TTC CAA GAT G-3`. PCR reactions were prepared in a final volumen of $25 \mu \mathrm{l}$ using Dream Taq ${ }^{\mathrm{TM}}$ PCR Master Mix 2X (Fermentas $^{\circledR}$ ), 0.1 $\mu \mathrm{M}$ of each primer and $20 \mathrm{ng}$ of DNA. Amplification

Table 1. Distribution of analyzed psittacines by province.

\begin{tabular}{cccc}
\hline Province & $\mathrm{VC}^{2}$ & Shelters $^{3}$ & Total \\
\hline San José & 51 & - & 51 \\
Alajuela & 11 & 32 & 43 \\
Puntarenas & 2 & 33 & 35 \\
Heredia & 15 & - & 15 \\
Cartago & 5 & 9 & 14 \\
Guanacaste & - & 8 & 8 \\
Limón & 2 & - & 2 \\
NR & 28 & 73 & 101 \\
Total & 114 & 155 & 269 \\
\hline
\end{tabular}

${ }^{1} \mathrm{NR}=$ Not reported; ${ }^{2} \mathrm{VC}=$ Birds submitted to veterinary clinics; ${ }^{3}$ Shelters $=$ Birds from shelters or rescue centers. 
Table 2. Distribution of the analyzed psittacines by species.

\begin{tabular}{ccccc}
\hline Species & $\mathrm{VC}^{1}$ & Shelters $^{2}$ & $\mathrm{NR}^{3}$ & Total \\
\hline Ara macao & 86 & 43 & 28 & 157 \\
Ara ambigua & 15 & 22 & - & 37 \\
Amazona autumnalis & 17 & 7 & - & 24 \\
Amazona ochrocephala & 17 & 4 & - & 21 \\
Ara ararauna & 8 & - & - & 8 \\
Amazona auropalliata & 3 & 3 & - & 6 \\
Aratinga finshi & 5 & - & - & 5 \\
Amazona farinosa & 2 & 1 & - & 3 \\
Amazona albifrons & 1 & 2 & - & 3 \\
Brotogeris jugularis & 1 & 1 & - & 2 \\
Pionus senilis & 2 & - & - & 2 \\
Amazona aestiva & 1 & - & - & 1 \\
Psittacus erithacus & 1 & - & - & 1 \\
Amazona oratrix & 1 & - & - & 1 \\
Ara militaris & 1 & - & - & 1 \\
Cacatua alba & 1 & - & - & 1 \\
Aratinga nana & 1 & - & - & 1 \\
Ara hibrido & 1 & - & - & 1 \\
Agapornis sp. & 1 & - & - & 1 \\
Total & 165 & 83 & 28 & 276 \\
\hline
\end{tabular}

${ }^{1} \mathrm{VC}=$ Birds submitted to veterinary clinics, ${ }^{2}$ Shelters $=$ Birds from shelters or rescue centers; ${ }^{3} \mathrm{NR}=$ Not reported.

programme consisted of an initial denaturation at $95^{\circ} \mathrm{C}$ for $5 \mathrm{~min}$, followed by 35 cycles of denaturation $\left(94^{\circ} \mathrm{C}\right.$ for $30 \mathrm{~s})$, alignment $\left(60^{\circ} \mathrm{C}\right.$ for $\left.30 \mathrm{~s}\right)$, extension $\left(72^{\circ} \mathrm{C}\right.$ for $30 \mathrm{~s}$ ) and a final extension at $72^{\circ} \mathrm{C}$ for $10 \mathrm{~min}$. PBFDV and APV DNA was kindly provided by the Clinic of Birds, Reptiles, Amphibians and Fish, Justus Liebig University, Giessen, Germany and used as positive controls; molecular biology grade water (Fermentas ${ }^{\circledR}$ ) was used as negative control. The PCR products were visualized by agarose gel electrophoresis $(2 \%)$ in TBE (Tris Base, boric acid, EDTA, pH 8, 0.5 M), stained with ethidium bromide $(0.5 \mu \mathrm{g} / \mathrm{ml})$. GeneRuler 100 bp DNA Ladder Plus (Sm 0321, Fermentas ${ }^{\circledR}$ ) was used as size marker. Samples that showed bands with the expected size were considered positive.

\subsection{Statistical Analysis}

A descriptive analysis was carried out using the results obtained from PCR, origin, species and clinical survey of the psittacines. Additionally, a logistic regression analysis using PROC LOGISTIC in $\mathrm{SAS}^{\circledR}$ program (SAS/ STAT $^{\circledR}$ version 9.2) was performed for the dependent variables presence/absence of PBFDV and APV. The independent variables analyzed were: origin of the birds (veterinary clinic or shelter), age (juvenile or adult), species, clinical symptoms (feather abnormality, beak deformity, others), and type of sample (blood or feather). The analysis was carried out for seven psittacine species (Ara ambigua, Ara macao, Amazona auropalliata, Amazona autumnalis, Aratinga finshi, Amazona ochrocephala and Ara ararauna), the others were excluded due to small sample size. Finally, to determine if PBFDV infection represented a risk factor for psittacines to become infected with APV, a Fisher test was applied [25].

\section{Results}

Of the total of 269 birds tested 53 (19.7\%) were positive to PBFDV by PCR (Figure 1(a)). PBFDV-positive samples belonged to 14 psittacine species, being the most frequent Amazona autumnalis (18/53) and Ara macao (12/53). The majority of positive birds were adults (51), 18 PBFDV-positive birds lived in shelters in the provinces of Cartago (5/18) and Puntarenas (13/18), and 35 had been presented at veterinary clinics for several reasons (Table 3). Only 8 PBFDV-positive birds from shelters and 12 PBFDV-positive birds presented to veterinary clinics reported feather abnormalities or beak deformity, whereas the remaining PCR positive psittacines $(62.3 \%)$ showed no symptoms. However, a total of 30 birds (9

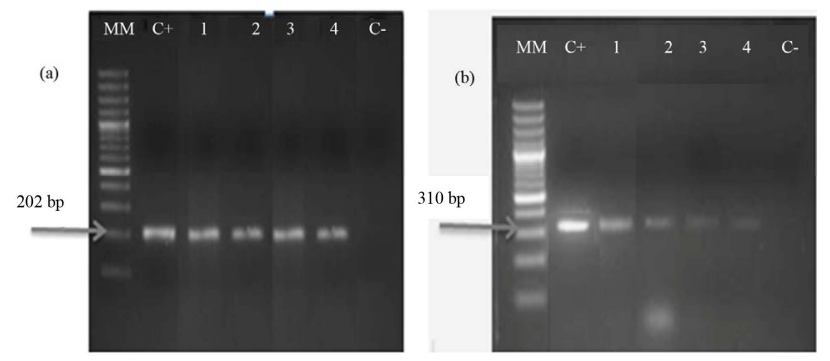

Figure 1. Gel electrophoresis of PCR products of PBFDV (a) and APV (b). (MM: molecular marker GeneRuler 100 bp DNA Ladder Plus; C+: positive control to PBFDV (a) and APV (b); 1 - 4: birds positive to PBFDV (a) and APV (b), $\mathrm{C}-$ : negative control).

Table 3. Description of PBFDV positive psittacines, according to origin and clinical symptoms.

\begin{tabular}{|c|c|c|c|c|c|}
\hline & $\begin{array}{c}\text { Feather } \\
\text { abnormality }\end{array}$ & $\begin{array}{c}\text { Beak } \\
\text { deformity }\end{array}$ & $\begin{array}{c}\text { Feather and beak } \\
\text { abnormalities }\end{array}$ & $\begin{array}{l}\text { Other/ } \\
\text { routine }\end{array}$ & Total \\
\hline Shelters ${ }^{1}$ & 7 & - & 1 & 10 & 18 \\
\hline $\mathrm{VC}^{2}$ & 8 & 3 & 1 & 23 & 35 \\
\hline Total & 15 & 3 & 2 & 33 & 53 \\
\hline
\end{tabular}

${ }^{1}$ Shelters $=$ Birds from shelters or rescue centers $;{ }^{2} \mathrm{VC}=$ Birds submitted to veterinary clinics; ${ }^{3} \mathrm{Other} /$ routine: Other clinical symptoms or presented to routine consultation. 
from shelters and 21 from veterinary clinics) reported clinical signs compatible with the disease and were PCR negative. PBFDV-DNA was detected only in feathers $(36 / 53)$, only in blood $(10 / 53)$, or in feathers and blood samples (7/53).

From the total of 269 birds 13 (4.8\%) tested positive to APV by PCR (Figure 1(b)). All 13 positive birds were adults, lived in shelters in the province of Puntarenas $(6 / 13)$ or had been presented at veterinary clinics (7/13), and belonged to 6 different species, being the most frequent Amazon auropalliata (4/13), Ara macao (3/13) and Amazona autumnalis (3/13). In 10 samples, DNA of APV was detected only in feathers, whereas the other three samples APV were detected in the blood DNA bank. In addition, 9 birds showed mixed infection with PBFDV. Mixed infections were detected in both, shelter birds (5/9) and birds' submitted to veterinary clinics (4/9), only 2 of these birds with mixed infections reported feather abnormality, while one showed unrelated symptoms (nasal and ocular secretions) and 6 did not report any symptoms (Table 4).

Logistic regression analysis of PBFDV determined only origin and sample type as significant. Birds proceeding from shelters were more likely to be infected with PBFDV than psittacine birds submitted to veterinary clinics $(\mathrm{OR}=3.25$, IC95\%: 1.367 - 7.703). In addition, DNA from PBFDV was more likely to be detected in

Table 4. Description of APV-positive psittacines, according to origin, clinical symptoms, and results of PBFDV in PCR.

\begin{tabular}{|c|c|c|c|c|}
\hline & Species & Origin & Symptoms & PBFDV \\
\hline 1 & Ara macao & $\mathrm{VC}^{1}$ & $\mathrm{NR}^{3}$ & - \\
\hline 2 & Ara macao & $\mathrm{VC}$ & NR & - \\
\hline 3 & Ara macao & $\mathrm{VC}$ & NR & - \\
\hline 4 & Amazon auropalliata & $\mathrm{VC}$ & Routine consultation & + \\
\hline 5 & Amazon auropalliata & Shelter $^{2}$ & No symptoms & - \\
\hline 6 & Amazon auropalliata & Shelter & No symptoms & + \\
\hline 7 & Amazon auropalliata & Shelter & Feather abnormalities & + \\
\hline 8 & Amazon auropalliata & Shelter & No symptoms & + \\
\hline 9 & Amazon auropalliata & Shelter & $\begin{array}{l}\text { Nasal and ocular } \\
\text { secretions }\end{array}$ & + \\
\hline 10 & Amazona autumnalis & $\mathrm{VC}$ & No symptoms & + \\
\hline 11 & Aratinga finshi & $\mathrm{VC}$ & No symptoms & + \\
\hline 12 & Amazona albifrons & Shelter & No symptoms & + \\
\hline 13 & Agapornis sp. & $\mathrm{VC}$ & Feather abnormalities & + \\
\hline
\end{tabular}

feathers than in blood (OR = 3.85, IC95\%: $0.118-0.571)$. Logistic regression analysis of APV determined also the variable origin as significant, being psittacines from shelters more likely to be infected with APV (OR $=5.35$, IC95\%: 1.259 - 22.770). Finally, birds infected with PBFDV were 6.24 times (IC 2.36 - 16.45) more likely to be infected with APV, than birds that were negative to PBFDV.

\section{Discussion}

This study reports for the first time the detection and prevalence of PBFDV (19.7\%) and APV (4.8\%) in psittacine birds in captivity in Costa Rica, determined by PCR. Regarding PBFDV, this agent has not been reported until now in Costa Rica. Studies carried out in Germany [21] and Taiwan [22] reported high prevalence, while in USA [19] and Italy [20] low prevalence were reported. One reason for the high prevalence determined in the present study, may be, that most of the analyzed samples belonged to adult birds, which were reported in the literature as subclinical carrier birds [6], which is in accordance with our findings, since only $37.7 \%$ of PCR positive psittacine birds showed feather abnormalities or beak deformity. Another reason for the high prevalence could be that PBFDV positive birds were found in the present study mainly in two shelters, where it is common that birds share cages, facilitating the transmission of the agent. Most of the shelters in Costa Rica do not have sanitary protocols and do not implement adequate disinfection measures in cages when new birds are introduced to the center. The present study however demonstrates the importance to use molecular techniques to detect birds carrying PBFDV. Other techniques used to diagnose PBFDV are immunohistochemistry and immunofluorescence, however they are either invasive or of low sensitivity, while detection of antibodies are not useful for detecting carriers, so that the use of PCR is recommended. DNA from PBFDV was detected especially in feathers, which is consistent with reports describing the main location of this virus in the follicle of feathers [7]. Logistic regression analysis confirmed these results, establishing that birds from shelters are more likely to be infected with PBFDV, also that PBFDV is more likely to be detected in feathers. It is recommended to carry out a diagnosis of PBFDV with this type of sample.

Regarding APV, a seropositivity of $9.37 \%$ in Ara macao was already determined in the country [23], differences can be explained, due to the different techniques used and the higher possibility of finding antibodies than antigens in a population. The prevalence determined in this study $(4.8 \%)$ is consistent with reports from Italy [20]. Logistic regression analysis established that birds from shelters are more likely to be infected with APV. 
Although APV was described to be located mainly in the feather follicle [27], in this study it was not possible to determine statistically significance, possibly due to the low percentage of positive birds found. The finding that birds infected with PBFDV are more likely $(\mathrm{OR}=6.24)$ to be infected with APV may be due to immunosupression caused by PBFDV, facilitating infection of APV and other agents $[4,5]$.

It can be concluded that the determined prevalences of PBFDV and APV established in the present study reflects the current situation of captive psittacines in the country. Our recommendation includes the molecular diagnosis of these viral agents PBFDV and APV in shelters and rescue centers, either when introducing birds, or before releasing them to wildlife in liberation programs.

\section{Acknowledgements}

Special thanks to Dr. Marcial Arrieta, Dr. Oscar Robert and Dr. Mauricio Jiménez who actively participated in this research, to Dr. Kinndle Blanco for her help and valuable advice, to the German Service of Academic Exchange (DAAD) for the scholarship awarded to Jessica Sheleby-Elias. This research was conducted in the framework of the project "Detection of infectious agents in wild birds of Costa Rica", project number NFEG05 of the Universidad Nacional.

\section{Resumen}

El virus de la enfermedad del pico y la pluma (Psittacine Beak and Feather Disease Virus, PBFDV), y el poliomaviurs aviar (APV) son las enfermedades virales más comunes en psitácidas, que afectan las plumas y la apariencia física de las aves. Entre 2005 y 2009 se recolectaron un total de 269 muestras de 19 especies de psitácidas presentadas en clínicas veterinarias y refugios y centros de rescate de vida silvestre de Costa Rica. Las especies más representativas de la muestra fueron Ara macao (157), Ara ambigua (37), Amazona autumnalis (24), Amazona ochrocephala (21) y Ara ararauna (8). Se determinó una prevalencia de $19.7 \%$ (53/269) para PBFDV y de 4.8\% (13/269) para APV utilizando la técnica de Reacción en Cadena de la Polimerasa (PCR). En un 3.3\% (9/269) de las aves se detectaron infecciones mixtas. El análisis estadístico determinó que existe mayor riesgo de encontrar los virus en aquellas aves que provienen de refugios y centros de rescate de vida silvestre, que en las que son presentadas en clínicas veterinarias, mientras que sólo para PBFDV se determinó mayor probabilidad de detectar el virus en plumas que en sangre. Se estableció que aves infectadas con PBFDV tienen 6.24 veces más probabilidad de infectarse con APV, que aquellas aves en las que no se detectó PBFDV. Este es el primer reporte de la presencia de PBFDV y APV en psitácidas en cau- tiverio de Costa Rica.

\section{REFERENCES}

[1] H. Katoh, H. Ogawa, K. Ohya and H. Fukushi, "A Review of DNA Viral Infections in Psittacine Birds," Journal Veterinary Medicine Science, Vol. 72, No. 9, 2010, pp. 1099-1106. doi:10.1292/jvms.10-0022

[2] D. A. Pass and R. A. Perry, "The Pathology of Psittacine Beak and Feather Disease," Australian Veterinary Journal, Vol. 61, No. 3, 1984, pp. 69-74. doi:10.1111/j.1751-0813.1984.tb15520.x

[3] B. W. Ritchie and K. Carter, "Avian Viruses: Function and Control," Wingers Publishing Inc., Florida, 1995.

[4] I. Ypelaar, M. R. Bassami, G. E. Wilcox and S. R. Raidal, "A Universal Polymerase Chain Reaction for the Detection of Psittacine Beak and Feather Disease Virus," Veterinary Microbiology, Vol. 68, No. 1-2, 1999, pp. 141148. doi:10.1016/S0378-1135(99)00070-X

[5] N. J. Schoemaker, G. M. Dorrestin, K. S. Latimer, J. T. Lumji, M. J. L Kik, M. H. van der Hage and R. P. Campagnoli, "Severe Leukopenia and Liver Necrosis in Young African Grey Parrots (Psittacus erithacus erithacus) Infected with Psittacine Circovirus," Avian Diseases, Vol. 44, No. 2, 2000, pp. 470-478. doi:10.2307/1592565

[6] H. Gerlach, "Virus," In: G. J. Harrison and L. R. Harrison, Eds., Clinical Avian Medicine and Surgery, WB Saunders Co Philadelphia, London, 1986, pp. 900-902.

[7] B. W. Ritchie, F. D. Niagro, K. S. Latimer, W. L. Steffens, D. Pesti, J. Ancona and P. D. Lukert, "Routes and Prevalence of Shedding of Psittacine Beak and Feather Disease Virus," American Journal Veterinary Research, Vol. 52, No. 11, 1991, pp.1804-1809.

[8] E. R. Jacobson, S. Clubb, C. Simpson, M. Walsh, C. D. Lothrop Jr., J. Gaskin, J. Bauer, S. Hines, G. V. Kollias and P. Poulos, "Feather and Beak Dystrophy and Necrosis in Cockatoos. Clinicopathologic Evaluations," Journal of American Veterinary Medicine Association, Vol. 189, No. 9, 1986, pp. 999-1005.

[9] S. L. Wylie and D. A. Pass, "Experimental Reproduction of Psittacine Beak and Feather Disease/French Molt," Avian Pathology, Vol. 16, No. 2, 1987, pp. 269-281. doi:10.1080/03079458708436374

[10] G. Bernier, M. Morin and G. Marsolais, "A Generalized Body Disease in the Budgerigar (Melopsittacus) Caused by a Papovavirus-Like Agent," Avian Diseases, Vol. 25, No. 4, 1981, pp. 1083-1092. doi:10.2307/1590087

[11] L. H. Bozeman, R. B. Davis, D. Gaudry, P. D. Lukert, O. J. Fletcher and M. J. Dykstra, "Characterization of a Papovavirus Isolated from Fledgling Budgerigars," Avian Diseases, Vol. 25, No. 4, 1981, pp. 972-980. doi: $10.2307 / 1590072$

[12] K. Hirai, H. Nonaka, H. Fukushi, S. Shimakura, T. Masegi and T. Mizoguchi, "Isolation of a Papova Like Agent from Young Budgerigars with Feather Abnormalities," Journal of Veterinary Science, Vol. 46, 1984, pp. 577-587. doi:10.1292/jvms 1939.46.577

[13] P. O. Wainwright, P. D. Lukert, R. B. Davis and P. Vill- 
egas, "Serological Evaluation of Some Psittaciformes for Budgerigar Fledgling Disease Virus," Avian Diseases, Vol. 31, No. 3, 1987, pp. 673-676. doi:10.2307/1590759

[14] R. Johne and H. Müller, "Avian Polyomavirus in Wild Birds: Genome Analysis of Isolates from Falconiformes and Psittaciformes," Archive Virology, Vol. 143, No. 8, 1998, pp. 1501-1512. doi:10.1007/s007050050393

[15] R. Johne and H. Müller, "The Genome of Goose Hemorrhagic Polyomavirus, a New Member of the Proposed Subgenus Avipolyomavirus," Virology, Vol. 308, No. 2, 2003, pp. 291-302. doi:10.1016/S0042-6822(02)00103-4

[16] G. E. Rossi and C. Tarantino, "Outbreak of Avian Polyomavirus Infection with High Mortality in Recently Captured Crimson's Seedcrackers (Pyrenestes sanguineus)," Journal of Wildlife Diseases, Vol. 41, No. 1, 2005, pp. 236-240.

[17] R. B. Davis, L. H. Boezeman, D. Gaudry, O. J. Fletcher, P. D. Lukert and M. J. Dykstra, "A Viral Disease of Fledgling Budgerigars," Avian Diseases, Vol. 25, No. 1, 1981, pp. 179-183. doi:10.2307/1589839

[18] H. Ogawa, T. Yamaguchi and H. Fukushi, "Duplex Shuttle PCR for Differential Diagnosis of Budgerigar Fledgling Disease and Psittacine Beak and Feather Disease," Microbiology and Immunology, Vol. 49, No. 3, 2005, pp. 227-237.

[19] E. De Kloet and S. R. de Kloet, "Analysis of the Beak and Feather Disease Viral Genome Indicates the Existence of Several Genotypes Which Have a Complex Psittacine Host Specificity," Archive Virology, Vol. 149, No. 12, 2004, pp. 2393-2412. doi:10.1007/s00705-004-0368-x

[20] E. Bert, L. Tomassone, C. Peccati, M. G. Navarrete and S. C. Sola, "Detection of Beak and Feather Disease Virus (BFDV) and Avian Polyomavirus (APV) DNA in Psittacine Birds in Italy," Journal of Veterinary Medicine B, Vol. 52, No. 2, 2005, pp. 64-68. doi:10.1111/j.1439-0450.2005.00823.x
[21] M. Rahaus and M. H. Wolff, "Psittacine Beak and Feather Disease: A First Survey of the Distribution of Beak and Feather Disease Virus Inside the Population of Captive Psittacine Birds in Germany," Journal of Veterinary Medicine B Infectious Diseases Veterinary Public Health, Vol. 50, No. 8, 2003, pp. 368-371. doi:10.1046/j.1439-0450.2003.00696.x

[22] C. M. Hsu, C. Y. Ko and H. J. Tsaia, "Detection and Sequence Analysis of Avian Polyomavirus and Psittacine Beak and Feather Disease Virus from Psittacine Birds in Taiwan," Avian Diseases, Vol. 50, No. 3, 2006, pp. 348353. doi:10.1637/7485-121105R.1

[23] I. Herrera, S. R. Khan, E. F. Kaleta, H. Müller, G. Dolz and U. Neumann, "Serological Status for Chlamydophila psittaci, Newcastle Disease Virus, Avian Polyoma Virus, and Pacheco Disease Virus in Scarlet Macaws (Ara macao) Kept in Captivity in Costa Rica," Journal of Veterianry Medicine B Infectious Diseases Veterinary Public Health, Vol. 48, No. 10, 2001, pp. 721-726.

[24] C. Drews, "Mascotas Silvestres en Hogares Ticos. Percepciones, Actitudes y Conocimientos (Wild Pets in Costa Ricans Homes. Perceptions, Attitudes and Knowledge)," Ambientico, Vol. 103, 2002, pp. 12-13.

[25] D. Wayne, "Bioestadística. Base Para el Análisis de las Ciencias de la Salud (Biostatistics. Basis for the Analysis of Health Sciences)," Limusa Wiley, México, 2002.

[26] R. Raue, R. Johne, L. Crosta, M. Bürkle, H. Gerlach and H. Müller, "Nucleotide Sequence Analysis of a $C_{1}$ Gene Fragment of Psittacine Beak and Feather Disease Virus Amplified by Real-Time Polymerase Chain Reaction Indicates a Possible Existence of Genotypes," Avian Pathology, Vol. 33, No. 1, 2004, pp. 41-50. doi: $10.1080 / 03079450310001636219$

[27] F. D. Niagro, B. W. Ritchie and K. S. Latimer, "Avian Polyomavirus. Discordance between Neutralizing Antibody Titers and Viral Shedding in an Aviary," Proceedings of Annual Conference Association Avian Veterinarians, 1991, pp. 22-26. 